\author{
Jakub Musiałczyk \\ Katedra Teorii Literatury \\ Uniwersytet Łódzki \\ kmdergeist@gmail.com
}

\title{
Co by było, gdyby Arystofanes miał Facebooka?
}

\section{Uwagi wstępne}

Przyjęło się myślenie, że "hejterstwo" jest domeną naszych czasów, więc badania dotyczące tego zjawiska skupiają się głównie na analizie wypowiedzi internetowych. Wydaje się jednak, że zaliczanie tego problemu do „chorób” XXI wieku i zawężenie go jedynie do przestrzeni internetu jest zbyt pochopne. Takie założenie zakłada bowiem, że obraźliwy język, personalne zaczepki i niepoparte argumentami znieważanie adwersarzy narodziły się wraz z Web 2.0, a wcześniej były w dyskusji publicznej nieobecne. Hejterstwo wymyka się jednoznacznym definicjom. Wydaje mi się, że terminem, który oddaje sens tego pojęcia, może być krytykanctwo, oznaczające niesłuszne, nierzeczowe i uciążliwe krytykowanie. Tym, co odróżnia "hejtowanie” od bezpodstawnego krytykowania, jest jednak między innymi anonimowość atakującego, zwalniająca go od odpowiedzialności za wypowiadane słowa.

W celu udowodnienia, że skłonność do krytykanctwa istnieje w człowieku od zawsze, chciałbym cofnąć się do $\mathrm{V}$ wieku przed naszą erą i poddać analizie wybrane komedie Arystofanesa, które można by, z pewnymi zastrzeżeniami, z dzisiejszej perspektywy nazwać „hejterskimi”. 
Zrozumienie krytyki uprawianej przez Arystofanesa wymaga przypomnienia realiów, w jakich żył - szczególnie kontekstu historycznego, politycznego i społecznego. Dzieciństwo Arystofanesa to najświetniejszy okres Aten - tzw. okres pięćdziesięciolecia (pentakontaeii), trwający od 480 do 431 roku, tzn. od bitwy pod Salaminą (480 p.n.e.), która zaważyła na zwycięstwie Greków nad Persami i zakończyła trwające dwadzieścia lat wojny perskie, do drugiej wojny peloponeskiej (431-404 p.n.e.), która przyniosła Atenom kompletną klęskę (zob. Wolski 2002: 172-183, 191-203).

Arystofanes urodził się około 445 roku, więc był świadkiem rozwoju ateńskiego imperium, sprawującego władzę nad związkiem morskim i przeobrażającego się w centrum kulturowe całej Grecji. To w Atenach w V wieku tworzył swoje rzeźby Fidiasz, to wtedy wybudowano Partenon, a swoje tragedie pisali Ajschylos, Sofokles i Eurypides. To w Atenach w V wieku działał Sokrates. Był to też czas największego rozwoju demokracji ateńskiej, w której władzę sprawował Demos-lud poprzez zgromadzenie ludowe, złożone z obywateli i organ wykonawczy - Radę Pięciuset, ale w praktyce władza należała do wybitnych przywódców, wybieranych na urząd stratega. I o ile Perykles, pełniący tę funkcję przez wiele lat, został zapamiętany jako mąż stanu, o tyle wraz w pogłębiającym się kryzysem, do władzy dochodzili demagodzy, przeciw którym ostro występował Arystofanes (Wolski 2002: 175). Jedną z najważniejszych cech demokracji ateńskiej była przysługująca obywatelom (tj. wolnym mężczyznom pochodzącym z Aten) wolność słowa, wykorzystywana przede wszystkim na zgromadzeniach ludowych, ale także - co postaram się wykazać $-\mathrm{w}$ komedii.

\section{Cechy komedii}

Komedia jako gatunek dramatyczny ma dwojakie źródła. Pierwsze z nich wskazuje na kult Dionizosa i wywodzi się z obchodzonych uroczyście co roku świąt poświęconych mu jako bogu winorośli, odradzającej się przyrody, życia. Kult ten miał charakter orgiastyczny, a celem obrzędów było wyzwolenie bujnych sił przyrody, urodzajności ziemi, rozrodczości, stąd duża swoboda i obsceniczność towarzyszące świętu i nikogo niebulwersujące. Nazwa gatunku, tj. komoidia („pieśń komosowa"), pochodzi od komosu, czyli świątecznego pochodu uczestników zabaw ku czci Dionizosa. Pieśni towarzyszące obchodom święta cechowało szyderstwo, sprośność i dosadne żarty (Srebrny 1984: 66), stąd w komedii staroattyckiej, której przedstawicielem był Arystofanes, można odnaleźć rubaszne dowcipy, skarykaturyzowanie, parodię, satyrę. Warto wspomnieć też o tym, że aktorzy oprócz masek 
i wypchanych brzuchów, mieli także przyczepianego fallusa jako symbol płodności (Łanowski 2005: XXII). Drugim źródłem komedii były doryckie widowiska bez chóru, ale z udziałem aktora, które miały charakter ludowych i farsowych scenek obyczajowych i mitologicznych (Wielechowska 2006: 350).

Połączenie „pieśni komosowej” i doryckiego mimu dało więc podstawy do powstania gatunku szczególnego. Komedia grecka V wieku cechowała się specyficzną tematyką i formą. Ówczesne problemy polityczne ${ }^{1}$ mieszały się z fantastyką (Sinko 1932: 376-378), a wszystko okraszone było: „z zasady nieco zwariowanym, fantastycznym, trochę z baśni, trochę z imaginacji poety, zawsze szokującym komizmem kontrastu $\mathrm{z}$ rzeczywistością, gigantycznym rozbudowanym żartem" (Łanowski 1997: 45). Komedii więc, w przeciwieństwie do tragedii, nie ograniczały żadne zasady — w niej wszystko mogło się wydarzyć.

Gatunkiem literackim spokrewnionym z komedią jest satyra, ponieważ jej zadanie to wyszydzanie określonych zjawisk społecznych, wydarzeń, cech ludzkich czy konkretnych osób. Cechuje ją, tak jak komedię, swobodny, obsceniczny ton i nieskrępowana forma. Mimo że satyra wywodzi się z tradycji rzymskiej, to aspekty satyryczne pojawiły się wcześniej w archaicznej poezji greckiej, a później także w komedii (Komornicka 2006: 675). Trzeba też pamiętać, że według mitologii w orszaku Dionizosowi towarzyszyli satyrowie - demony przyrody, dlatego mężczyzn biorących udział w komosie nazywano satyrami, a kobiety - na wzór bachantek - menadami. Postaci satyrów wykorzystywał także dramat satyrowy, przestawiający humorystycznie i wesoło motywy mitologiczne. Satyrowie tworzyli w nim chór - główny element dramatu - który swoim zachowaniem stwarzał sytuacje komiczne (Steffen 2006: 181-182).

\section{Kilka słów o Arystofanesie}

Arystofanes jest jedynym twórcą komedii staroattyckiej, którego utwory w całości przetrwały do dzisiaj. Nie znamy dokładnej biografii komediopisarza — wiadomo jedynie, że był synem średniozamożnego ziemianina, który jednak zapewnił mu staranne wykształcenie. W 427 roku napisał swoją pierwszą komedię - Biesiadników, którą wystawić musiał pod obcym nazwiskiem, dlatego przyjmuje się, że był

\footnotetext{
1 „Komediopisarze włączali się w debatę nad funkcjonowaniem demokracji ateńskiej, a także komentowali literaturę i modne prądy umysłowe epoki. Ulubionym celem satyry komediowej były wszelkie osoby prominentne, zwłaszcza wpływowi politycy, których imiennie lub pod czytelnym pseudonimem zaczepiano, poniżano, wyśmiewano i parodiowano, korzystając pełną ręką z demokratycznej wolności słowa" (Bartol, Danielewicz 2011: 34).
} 
wtedy jeszcze niepełnoletni. Także data śmierci nie jest pewna - badacze uznają rok 385 za najbardziej prawdopodobny (Sinko 1932: 395).

W 426 roku wystawił komedię Babilończycy, niezachowaną do dziś, którą rozpoczął wielką kampanię przeciw Kleonowi, przywódcy stronnictwa skrajnie demokratycznego. W sztuce tej atakował Arystofanes zasady ustrojowe rządzące ateńską demokracją, takie jak wybieranie urzędników przez losowanie i głosowanie. Chórem uczynił sojuszników ateńskich przedstawionych jako niewolników Demosa, czyli ludu. Ponadto zrobił to w czasie święta, kiedy w polis obecni byli goście - sojusznicy ateńscy. Kleon wystąpił wtedy o ukaranie artysty, ale nie wiadomo do końca, jak sprawa się skończyła (Łanowski 2005: XXVIII). Niezrażony autor rok później wystawił kolejną sztukę - Acharnejczyków, w której przedstawił historię Prawogodziwca, chłopa zmęczonego wojną, który postanowił kupić dla siebie pokój, by bez przeszkód żyć w spokoju i handlować z wrogiem. Jego antagonistą był Lamachos, postać autentyczna - wódz ateński, wyraziście skarykaturowany (Srebrny 1984: 444). Warto wspomnieć, że tą komedią Arystofanes wygrał agon, czyli konkurs na najlepszą sztukę, co oznacza, że widownia ateńska rozumiała i doceniała tego typu komizm².

Wiadomo, że spod pióra Arystofanesa wyszły 44 utwory, choć cztery z nich uważano za nieautentyczne. Do czasów dzisiejszych zachowało się jedenaście (Łanowski 2005:XXXV). Poszukując w utworach Ateńczyka najwyraźniejszych śladów „hejterstwa”, należy ograniczyć się do kilku komedii: Rycerzy, Os, Chmur i Żab.

\section{Walka z Kleonem}

Arystofanes w swoich sztukach zaciekle walczył z Kleonem, bogatym właścicielem garbarni, który był zwolennikiem prowadzenia wojny ze Spartą (Wolski 2002: 194). Polityk ten starał się za wszelką cenę utrzymać władzę, posuwając się często do zastraszania i podstępów ${ }^{3}$. Komediopisarz, jako zagorzały pacyfista, pamiętający

2 Stefan Srebrny zauważa, że bohaterowie sztuk Arystofanesa wzięci z życia „(...) są, oczywiście, jaskrawie skarykaturowane; są postaciami z rzeczywistego życia, ale równocześnie to pewne tradycyjne maski komediowe, groteskowe schematy komiczne (...). Taki Lamachos — to nie tylko karykatura znanej wszystkim osobowości, ale buńczuczny, krzykliwy i nadęty Capitano" (Srebrny 1984: 444).

3 Jednym z dowodów Arystofanesa na nieuczciwe zachowania Kleona jest zwycięstwo Ateńczyków nad Spartanami na wyspie Sfakterii w 425 roku, bowiem wygrana bitwa była zasługą wodza Demostenesa - Kleon zaś zręcznie je sobie przypisał, co komediopisarz wyraźnie w Rycerzach sugerował (Steffen 1957: 120). Ze zdaniem Wiktora Steffena nie zgadza się Kazimierz Kumaniecki, pisząc o „stronniczości Arystofanesa”, który „z natarczywością propagandzisty (...) i wbrew prawdzie historycznej odbiera Kleonowi zwycięstwo" (Kumaniecki 1957: 30). 
problemy z wystawionymi wcześniej Babilończykami, miał w Kleonie głównego wroga, z którego uczynił symbol ułomności systemu demokratycznego.

W wystawionych w 424 roku Rycerzach Arystofanes rozpoczął otwartą wojnę z demagogiem. Przedstawił go jako złodzieja, oszusta i łapówkarza. Autor nadał mu w sztuce imię Paflagon, a jest to imię niewolnicze, które kojarzy się dodatkowo z greckim „bełkotać” (Ławińska-Tyszkowska 2001: 95) - Kleon podobno niewyraźnie mówił. Ponadto takie imię podważa attyckie pochodzenie polityka, co w tamtych czasach było bardzo silną obelgą (Łanowski 2005: XXX). Paflagon jest w komedii sługą Demosa-Ludu, zgrzybiałego, bezwolnego starca, którym można sterować i którego można przekupić byle przysmakiem. Tak tę relację opisuje sługa:

Pan nasz, z wiejska gburowaty, bobogryzek, drażliwy i do gniewu skory, zowie się Lud Pniksowiec - staruszek przygłuchy, tetryk, zrzęda. On tedy, zeszłego miesiąca, na jarmarku nowego kupił niewolnika - garbarza Paflagona, łajdaka, oszczercę. Ten to skóropaflagon, jak tylko wywęszył starego obyczaje, wnet zaczął pod niego podłazić, schlebiać, merdać ogonem, tumanić okrawkami swych skórek. Ludku — mówił - luby, tę jedną sprawę rozsądź - i odpocznij w łaźni. Przekąś - pociągnij — zakąś... Masz tu trzy obole. Podać ci podwieczorek?... i co tylko który z nas dla pana przyrządzi, wnet ściąga i panu ofiaruje od siebie. (Arystofanes 1977: 38)

I jeszcze jeden fragment, dobitnie pokazujący stosunek artysty do polityka:

Przed Paflagonem nic się nie ukryje. Przecie on „wszystko widzi”... Jedną nogą stoi w Pilosie, drugą nogę ma na Zgromadzeniu i gdy się tak rozkraczył, kuper jego gości w Rozdziawiłach, rączyny w Zagrabiszkach, myśli w Złodziejskiej Woli.

(Arystofanes 1977: 39)

Choć Arystofanes nie powiedział tego wprost, widzi on Kleona jako olbrzyma stojącego jedną nogą na Pylos (tj. tam, gdzie odbyła się zwycięska dla niego bitwa), drugą na rynku ateńskim, wypróżniającego się i zagarniającego rękami łapówki. Trudno chyba o dosadniejszy opis.

Innym utworem, w którym Arystofanes krytykuje Kleona, ale przede wszystkim system sądownictwa, są wystawione w 422 roku Osy. Autor przedstawił w nich konflikt ojca - Filokleona, sędziego i weterana wojen perskich, którego jedynym zajęciem jest sprawowanie sądów oraz syna - Bdelykleona (Mierzikleona), pragnącego zmusić ojca do rezygnacji z sądzenia, w zamian oferując mu możliwość orzekania w sprawach domowych, np. w sprawie psa kradnącego ser. $\mathrm{Na}$ imionach nie kończą się jednak aluzje do Kleona — za postaciami psów kryją się ateńscy przywódcy. Oskarżony o kradzież pies ajksoński Labes to Laches, wódz, który został oskarżony przez Kleona — przedstawionego w komedii jako 
psa kydatenajskiego - o nieuczciwe wzbogacenie się w czasie wyprawy wojennej. Arystofanes w Osach po raz kolejny, tym razem za pośrednictwem aluzji, oskarżył przywódcę demokratów o nadużywanie władzy i fingowanie procesów dla własnych korzyści.

\section{Wyśmiewanie sofistów poprzez Sokratesa}

Atakowany przez komediopisarza był także Sokrates i sofiści. Sokratesa Arystofanes nie rozumiał, tak jak większość Ateńczyków utożsamiających niejasne wywody filozofa z naukami sofistów, lub rozumieć nie chciał (Wolski 2002: 189). Poza tym Sokrates, jako osoba znana, był postacią doskonałą do skarykaturyzowania (Steffen 1957: 130)4. W Chmurach, wystawionych w 423 roku komediopisarz przedstawił filozofa jako mędrka, który wdaje się w pseudonaukowe spekulacje, a tak naprawdę snuje nic nie warte rozważania, na przykład:

STUDENT: Zadał mu kiedyś Chajrefon pytanie, którędy — sądzi — komar serenadę swą odprawuje: przodem czy też zadem.

STREPSJADEs: Cóż więc Sokrates o komarze orzekł?

Student: Wnętrzności jego - twierdzi - są jak stożek. Więc kiedy komar przez tę ciasną szparę chce ulżyć sobie i popuścić parę, to tyłem podźwięk wydaje nadobny.

STREPSJADES: Więc tyłek jego trąbie jest podobny. Jakże sub-tylnie wyłożył tę rację! Nie przegra nigdy procesu ów filut, co zna wnętrzności komara na wylot.

(Arystofanes, 1977: 128)

Arystofanes kreuje w swojej komedii Sokratesa na szarlatana naciągającego swoich uczniów i robiącego im „pranie mózgów”. Bohaterem sztuki jest niezbyt mądry chłop, który wysyła swojego nieposłusznego i rozrzutnego syna na naukę do filozofa, by ten nauczył go retoryki. Chłopak po ukończeniu szkoły jest zupełnie zdeprawowany — bije ojca, argumentując:

4 Wiktor Steffen tłumaczył: „Jak zwykle w takich wypadkach, gdy chodziło o napiętnowanie jakiegoś szerszego lub ogólnie przejawiającego się prądu społecznego, tak i w tym wypadku musiał poeta rozejrzeć się za jakimś osobnikiem, który byłby typowym przedstawicielem danego zjawiska i który mógłby na scenie reprezentować zespół pojęć zwalczanych poetę. Nie znalazłszy wśród sofistów dość popularnej jednostki wybrał sobie Arystofanes jako ich przedstawiciela Sokratesa, którego absolutnie nic nie łączyło z sofistami, ale który posiadał cechy potrzebne sztuce. Był on znany społeczeństwu ateńskiemu jako filozofujący dziwak, zaczepiający na rynku przekupki i przechodniów na ulicy i przekazujący im swoje głęboko przemyślane prawdy (...) toteż przeciętni Ateńczycy uważali go niewątpliwie za przedstawiciela nowej nauki sofistycznej i spoglądali na niego pogardliwie, choćby ze względu na jego wygląd zewnętrzny i niedbałość w ubiorze" (Steffen 1957: 130). 
FEJdipPIDEs: Pomnę, nieraześ mi dzieckiem do skóry się dobrał.

STREPSJADES: W troscem robił to ojcowskiej, dla twojego dobra.

FEJDippides: Więc i ja też walić w trosce będę cię synowskiej, jeśli prawda to, że bicie jest wyrazem troski. Czemuż ty masz nietykalnym być, a ja nie? Przecie i ja wolny człowiek. Powiesz: „W dyscyplinie dziecię chować trzeba”. A czyż starzec to nie dzieciak duży, co na lanie, kiedy zbłądził, podwójne zasłużył?

STREPSJAdES: Jest ustawa, aby ojca otaczać honorem.

FEJdippides: A któż inny, jak nie człowiek - ustawy autorem? Jak on niegdyś „Czcijcie ojców” nakazywał starym, wydać prawo „Bijcie ojców” - moim jest zamiarem.

(Arystofanes 1977: 190-191)

Warto jeszcze zaznaczyć, że w czasie wystawiania Chmur w teatrze był także Sokrates, jednak jego reakcja była zupełnie inna niż Kleona: według anegdoty Sokrates wstał z miejsca i pokazał się wszystkim, by widzowie mogli porównać, czy maska wykonana dla aktora grającego filozofa jest podobna do samego Sokratesa. Świadczy to o dystansie filozofa do samego siebie i o jego zrozumieniu idei komizmu Arystofanesa.

\section{Rozliczenie z Eurypidesem}

Ostatnią postacią, szczególnie często atakowaną przez Arystofanesa, był Eurypides. Komediopisarz w dwóch swoich utworach odniósł się do słynnego tragika. I o ile w pierwszym $\mathrm{z}$ nich, Thesmoforiach z 411 roku, głównym narzędziem ataku jest parodia techniki poetyckiej wyśmianego twórcy, o tyle w Żabach z roku 405 poddał Arystofanes surowej krytyce zawarte w dziełach zmarłego rok wcześniej dramaturga idee. Stwierdził, że przez sofistyczną wykrętność Eurypides zacierał w swoich utworach granicę między dobrem i złem, kwestionował istnienie bogów i zamiast podnosić morale Ateńczyków, osłabiał je.

Fabuła komedii jest następująca: tęskniący za Eurypidesem Dionizos udaje się do Hadesu, by go stamtąd wyprowadzić. Przebrany za Heraklesa przeprawia się ze swoim niewolnikiem przez jezioro, by uczestniczyć w sporze o pierwszeństwo między Ajschylosem i autorem Trojanek. Dionizos, będący sędzią, ku swojemu zdziwieniu zabiera ze sobą do świata żywych twórcę Siedmiu przeciw Tebom, okazuje się bowiem, że w dyskusji tragików Eurypides traci wszystkie argumenty przemawiające na jego korzyść. Co istotne, kwestią rozstrzygającą na rzecz Ajschylosa było zapytanie poetów o zdanie na temat sposobu naprawy sytuacji politycznej w Atenach. Przegrana Eurypidesa podkreśliła poglądy Arystofanesa, który opowiadał się 
wyraźnie za bardziej „konserwatywną” wersją dramatu, oskarżając twórcę Medei o odheroizowanie tragedii (Turasiewicz 1977: 27).

Mimo że Żaby to komedia literacka, w której autor posługiwał się głównie parodią stylu i języka Eurypidesa, to należy też zauważyć, że Arystofanes zaatakował dopiero rok wcześniej zmarłego twórcę, czyniąc w tekście czytelne aluzje do jego życia osobistego, np. wytykając mu niewierność żony:

Dionizos: Przedstawiałeś na scenie to, co miałeś w domu.

EURYPIDES: Cóż moje bohaterki zaszkodziły komu?

AJschyLos: Tyś niewiasty nauczył jak szukać pokuty za niewierność małżeńską w kielichu cykuty.

EURYPIDES: A czyż zdrada małżeńska nie zdarza się w życiu?

AjschyLos: Tak, lecz brzydotę trzymać należy w ukryciu (...).

(Arystofanes 1977: 506)

\section{Czy Arystofanes był „hejterem”?}

Autor $\dot{Z} a b$ w swoich komediach wykorzystywał wszystkie dostępne mu chwyty: potrafił zgodnie $\mathrm{z}$ duchem komedii przytaczać sprośne dowcipy i kazać swoim bohaterom wyzywać się od „pedałów”, zdarzało mu się wykorzystywać czyjś wygląd, by łatwiej go ośmieszyć (jak na przykład Sokratesa), i atakować niemogącego się już bronić Eurypidesa. Wykorzystywał wiedzę o życiu prywatnym swoich antagonistów i posuwał się do insynuacji po to, by podważyć ich autorytet. Przeinaczał i przekręcał imiona i nazwy, pokazując ich wieloznaczność. Bywał stronniczy i niesprawiedliwy w ocenie, mimo świadomości siły oddziaływania jego utworów.

Trzeba również pamiętać o tym, że miał odwagę jako jedyny wystąpić przeciw Kleonowi - kiedy wystawiał Rycerzy nie mógł znaleźć nikogo, kto by odważył się wykonać maskę polityka i ostatecznie podobno sam zagrał jego rolę (Steffen 1957: 122). I o ile zdarzało mu się przekraczać granice, choć i to nie jest do końca pewne, bo wiedzy o utworach innych autorów komedii mamy bardzo mało, to jego krytyka w ogromnej części była uzasadniona, poparta argumentami i podpisana jego imieniem. Przytoczone przeze mnie przykłady są wyborem najbardziej skrajnych i wyrazistych egzemplifikacji, choć właściwie cała twórczość tego komediopisarza ma prześmiewczy charakter. Nie można jednak zapomnieć, że wszystkie swoje opinie wyrażał Arystofanes w komedii, która rządziła się swoimi prawami. 
Należy więc wyjaśnić jeszcze szerzej istotę staroattyckiej komedii, odnosząc się do przedstawianej w niej tak często polityki. Stefan Srebrny zauważa:

(...) Tymczasem rzecz staje się zupełnie jasna, gdy należycie uprzytomnimy sobie, że mamy do czynienia z ko me dią, czyli z rodzajem sztuki, który, jeśli tylko jest wolny i niczym nie skrępowany, jak to właśnie miało miejsce w Atenach, musi wyszydzać to, co w danej chwili stoi u szczytu i u steru, bo jedynie w ten sposób przejawiać może swą istotę. Gdyby w Atenach V wieku rządy były arystokratyczno-oligarchiczne, bez wątpienia komedia stałaby ma gruncie radykalnej demokracji. (...) Smagając współczesność, komedia zawsze przeciwstawia jej „dawne dobre czasy”; jest to jeden ze stale powtarzających się i psychologicznie bardzo zrozumiałych jej motywów. W związku z tym wyszydza komedia stale wszelkie dalej idące nowatorstwo, zarówno w życiu społecznym, jak i w życiu umysłowym, w wychowaniu w filozofii, w literaturze i sztuce 5 . (Srebrny, 1984: 81)

Widać więc, że komedia była dla Greków czymś więcej niż źródłem obscenicznego komizmu i satyry. Wykorzystując dane jej narzędzia, poruszała trudne tematy, diagnozowała problemy i przedstawiała społeczne niepokoje.

Wydaje się więc, że odpowiedź na postawione przeze mnie w tytule prowokujące pytanie nie jest ani łatwa, ani jednoznaczna. Facebookiem dla Arystofanesa był teatr - medium potężne i oddziałujące na Ateńczyków tak, jak internet na żyjących w XXI wieku. Autor Chmur był świadom jego siły i potrafił tę siłę wykorzystać. To za pomocą teatru wyrażał swoje zdanie, krytykował, chwalił, czasem „hejtował”. I sądzę, że gdyby Arystofanes dziś pisał to, co myśli, na Facebooku, tak jak kiedyś robił to w komediach, nikt niestety na niego nie zwróciłby uwagi, bo to, co czasem razi czytelnika komedii staroattyckich, rzadko kiedy razi przeciętnego użytkownika internetu.

Na koniec chciałbym przywołać myśl Johanna Gustava Bernharda Droysena, który - wydaje mi się — niezwykle trafnie oddał problem oceny twórczości Arystofanesa:

Zwykle uważa się Arystofanesa za człowieka bardzo patriotycznego, bardzo szanownego, bardzo moralnego, wyobraża się go jako rycerskiego dżentelmena, który zasłania się roześmianą maską, aby z głęboką powagą moralność radzić, co jest korzystne dla państwa itd. W licznych rozprawach filologicznych i filozoficznych dowodzono, że w jego komediach mieści się najwyższa mądrość polityczna i najwyższa moralność, jak gdyby

5 Trochę inny punkt widzenia przedstawia Anna M. Komornicka: „Jednym słowem ośmiesza on [Arystofanes - J.M.] wszystko co tworzy ustrój w którym żyje, łącznie z metodami rządzenia. Co więcej, paradoks polega na tym, że w świetle komedii demokraci okazują nieufność w stosunku do ludzi, których sami wybrali na te stanowiska. Myliłby się jednak grubo ten, kto by sądził, że Arystofanes atakuje samą istotę demokracji, demokrację jako taką" (Komornicka, 1997: 310). 
ich wartość estetyczna zależała od szlachetnych motywów i zacnych tendencji. Gdyby się je nawet w pełni przyjęło na podstawie wyznań i - samochwalstwa w parabazach, to i tak trzeba by uznać, że w wyborze środków, prowadzących do dobrego, postępował Arystofanes dość - dwuznacznie: oczerniał, by piętnować oszczerców; przeciw bezczelności demagogów wysuwał jeszcze bezczelniejszych zbawców; z ubolewaniem nad upadkiem religii łączył - bluźnierstwa; pławiąc się w scenach i słowach zbyt „naturalnych" i nieprzyzwoitych, grzmiał przeciw upadkowi obyczajów i starej dyscypliny. Tak stawiając pod pręgierz współczesność, sam wyrażał ją najlepiej w swoich - błędach. (Droysen, cyt za: Sinko 1932: 425)

Rozdzielenie przez Droysena treści od formy w komediach Arystofanesa uwalnia od przymusu jednoznacznej oceny jego twórczości. Sposoby, które komediopisarz wykorzystywał, by uwypuklić ważne według niego problemy, można nazwać hejterskimi. Należy jednak pamiętać o tym, że autor $\dot{Z} a b$ brał za swoje utwory i zawarte w nich oskarżenia odpowiedzialność oraz że czyniona przezeń krytyka nie była bezcelowa, ponieważ miała za zadanie unaocznić i wyeksponować to, co według Arystofanesa w otaczającym go świecie było złe.

\section{Bibliografia}

Arystofanes (1977), Chmury [w:] tegoż, Komedie wybrane, przeł. A. Sandauer,

S. Srebrny, oprac. R. Turasiewicz, Wydawnictwo Literackie, Kraków.

Arystofanes (1977), Rycerze [w:] tegoż, Komedie wybrane, przeł. A. Sandauer,

S. Srebrny, oprac. R. Turasiewicz, Wydawnictwo Literackie, Kraków.

Arystofanes (1977), Żaby [w:] tegoż, Komedie wybrane, przeł. A. Sandauer, S. Srebr-

ny, oprac. R. Turasiewicz, Wydawnictwo Literackie, Kraków.

Bartol Krystyna, Danielewicz Jerzy (2011), Komedia grecka. Od Epicharma do Menandra, PWN, Warszawa.

Komornicka Anna M. (1997), „Demokracja” i „demagogia” w świetle komedii Arystofanesa, „Eos” t. 84, z. 2.

Komornicka Anna M. (2006), Satyra [w:] Słownik rodzajów i gatunków literackich, G. Gazda, S. Tynecka-Makowska (red.), Universitas, Kraków. 
Kumaniecki Kazimierz (1957), Komedia Arystofanesowska w walce o pokój [w:] Arystofanes. Materialy sesji naukowej Komitetu Nauk o Kulturze Antycznej PAN, O. Jurewicz (red.), Zakład im. Ossolińskich - Wydawnictwo PAN, Wrocław. Łanowski Jerzy (1997), Granice żartu. Z zagadnień komizmu arystofanejskiego, „Meander”, nr 1.

Łanowski Jerzy (2005), Wstęp [w:] Arystofanes, Komedie, przeł. i oprac. J. Ławińska-Tyszkowska, Zakład Narodowy im. Ossolińskich, Wrocław.

Ławińska-Tyszkowska Janina (2001), Wstęp [w:] Arystofanes, Komedie, t. I, przeł. i oprac. J. Ławińska-Tyszkowska, Prószyński i S-ka, Warszawa.

Sinko Tadeusz (1935), Literatura grecka, t. I cz. 2, Polska Akademia Umiejętności, Kraków.

Srebrny Stefan (1984), Teatr grecki i polski, PWN, Warszawa.

Steffen Wiktor (1957), Rola karykatury w komediach Arystofanesa [w:] Arystofanes. Materialy sesji naukowej Komitetu Nauk o Kulturze Antycznej PAN, O. Jurewicz (red.), Zakład im. Ossolińskich - Wydawnictwo PAN, Wrocław.

Steffen Wiktor (2006), Dramat satyrowy [w:] Słownik rodzajów i gatunków literackich, G. Gazda, S. Tynecka-Makowska (red.), Universitas, Kraków.

Turasiewicz Romuald (1977), Wstęp [w:] Arystofanes, Komedie wybrane, przeł.

A. Sandauer, S. Srebrny, oprac. R. Turasiewicz, Wydawnictwo Literackie, Kraków. Wielechowska Katarzyna (2006), Komedia [w:] Słownik rodzajów i gatunków literackich, G. Gazda, S. Tynecka-Makowska (red.), Universitas, Kraków. Wolski Józef (2002), Historia powszechna. Starożytność, PWN, Warszawa. 


\title{
Jakub Musiałczyk
}

\section{Co by było, gdyby Arystofanes miał Facebooka?}

What Would Have Happened if Aristophanes Had a Facebook Profile?

Słowa kluczowe: Arystofanes, komedia staroattycka, teatr grecki, hejterstwo, krytyka

Key words: Aristophanes, Old Comedy, Greek theatre, hatred, criticism

\section{Streszczenie}

Celem pracy jest omówienie komedii Arystofanesa pod kątem zawartej w nich krytyki władz ateńskich i demokracji, Sokratesa i sofistów oraz Eurypidesa i jego poglądów. Analiza dotyczy argumentów, języka i środków, jakimi posługiwał się Arystofanes (żarty, aluzje, przeinaczanie nazw własnych), by wyrazić negatywną, często radykalną, opinię na określony temat. Przedstawiona zostanie także reakcja widzów na komedie Arystofanesa i atakowanych Greków (Kleona i Sokratesa). Autor stara się również wskazać różnice pomiędzy krytyką komediopisarza a dzisiejszym „hejterstwem”.

\begin{abstract}
The aim of this study is to discuss the Aristophanes' comedies in light of criticism towards Athens authorities, democracy, Socrates, the sophists as well as Euripides. The analysis concerns the arguments, language and forms of expression used in his compositions. Aristophanes restored to such measures in order to express his negative, sometimes even radical, opinion on certain topics. The study includes the presentation of the viewers' and insulted Greeks' reaction to the comedies. Additionally, the author tries to outline the differences between the comedy writer and current hatred.
\end{abstract}

